\title{
Functional Analysis of Degradative Enzymes for Hydroxyproline-linked $\beta$-L-Arabinofuranosides in Bifidobacterium longum
}

\author{
Bifidobacterium longum が生産する $\beta$ - アラビノオリゴ糖鎖分解酵素群の機能解析
}

\author{
Fujita, Kiyotaka ; Kitahara, Kanefumi ; and Suganuma, Toshihiko \\ Faculty of Agriculture, Kagoshima University, Korimoto, Kagoshima 890-0065, Japan \\ FAX: 81-99-285-8639, E-mail: kfujita@ms.kagoshima-u.ac.jp
}

(Received on August 31, 2012, accepted on September 13, 2012)

\begin{abstract}
Key Words: extensin, hydroxyproline-rich glycoprotein, $\beta$-L-arabinofuranosides, Bifidobacterium longum, arabinofuranosidase, prebiotics
\end{abstract}

\begin{abstract}
$\beta$-L-Arabinofuranosides are hydroxyproline (Hyp)linked sugar chains of extensin observed in plant cell wall fractions. Despite the broad distribution of $\beta$-Larabinofuranosyl residues in plants, degradative enzymes have not yet been identified. In 2011, we cloned and characterized the first degradative enzymes for Hyp-linked $\beta$-L-arabinofuranosides from Bifidobacterium longum. These enzymes were composed of a glycoside hydrolase (GH) family $43 \alpha$-L-arabinofuranosidase (HypAA) releasing

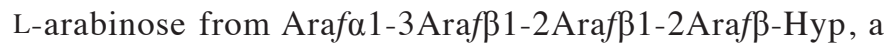
GH121 $\beta$-L-arabinobiosidase (HypBA2) releasing Araf $\beta 1$ $2 \operatorname{Araf}\left(\beta-\mathrm{Ara}_{2}\right)$ from Araf $\beta 1-2 \mathrm{Araf} \beta 1-2 \mathrm{Ara} f \beta-\mathrm{Hyp}$, and a GH127 $\beta$-L-arabinofuranosidase (HypBA1) degrading $\beta$ - $\mathrm{Ara}_{2}$ to $\mathrm{L}$-arabinose. These enzymes are encoded in a conserved gene cluster on several B. longum genomes, but not in genome sequences of other intestinal bacteria. Hyp-linked $\beta$-L-arabinofuranosides were utilized as carbohydrate sources by $B$. longum. This review presents the functional features of enzymes for Hyp-linked $\beta$-L-arabinofuranosides and the predicted metabolic pathway in B. longum.
\end{abstract}

\section{A. Introduction}

L-Arabinose residues are the main constituents of sugars in plant cell walls, and they are mostly present in the form of $\alpha$-L-furanose in polysaccharides such as arabinan, arabinoxylan, and pectic arabinogalactan. Glycoside hydrolases involved in the degradation of $\alpha$-Larabinofuranosides are present in 6 glycoside hydrolase $(\mathrm{GH})$ families (GH3, GH43, GH51, GH54, GH62, and GH93) in the CAZy database. In addition, degradative enzymes for $\alpha$ - and $\beta$-L-arabinopyranoside linkages were also found in the GH42 and GH27 families, respectively $(1,2)$. On the other hand, $\beta$-L-arabinofuranoside linkages constitute sugar chains of hydroxyproline-rich glycoproteins (HRGPs), which are known
要 約

$\beta$-アラビノオリゴ糖鎖は、植物細胞壁に含まれる糖タン パク質であるエクステンシンのハイドロキシプロリン (Hyp) 結合型糖鎖である。しかし、 $\beta$-L-アラビノフラノシド結合が 植物に広く分布するにもかかわらず、その分解酵素はこれま で報告されていなかった。2011 年に、我々は $\beta$-アラビノオリ ゴ糖鎖を分解する酵素群の Bifidobacterium longum からのク ローニングと性質決定に初めて成功した。本酵素群は、Araf

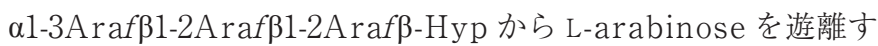
る GH43 $\alpha$-L-arabinofuranosidase (HypAA)、Araf $\beta 1-2 A r a f \beta 1$ 2ArafB-Hyp から Araf $\beta 1-2 A r a f\left(\beta-\mathrm{Ara}_{2}\right)$ を遊離する GH121 $\beta$-Larabinobiosidase (HypBA2)、遊離された $\beta$-Ara ${ }_{2}$ をL-arabinose に分解する GH127 $\beta$-L-arabinofuranosidase (HypBA1)によっ て構成されていた。本酵素群はB. longum ゲノム上で一つの 遺伝子クラスターを形成していたが、他の腸内細菌のゲノム 上には保存されていなかった。また、B. longum は $\beta$-アラビ ノオリゴ糖鎖を資化することができた。本総説では $\beta$-アラビ ノオリゴ糖鎖分解酵素群の機能性と B. longum で予想される 代謝経路について紹介する。

\section{A.はじめに}

L-arabinose は植物細胞壁における主要な構成糖であり、 arabinan や arabinoxylan や arabinogalactan 等の多糖におい てその多くが $\alpha$-L- フラノース型として存在している。 $\alpha-\mathrm{L}-$ ア ラビノフラノシド (Araf) 結合を加水分解する酵素は、CAZy データーベースに打いて 6 グループの糖質分解酵素 $(\mathrm{GH})$ ファ ミリー(GH3、GH43、GH51、GH54、GH62 およびGH93)に 分類されている。また、アラビノピラノシド結合に作用す る酵素として GH42 $\alpha$-L-arabinopyranosidase や GH27 $\beta$-Larabinopyranosidase が報告されている $(1 、 2)$ 。一方、 $\beta$-Lラビノフラノシド結合はハイドロキシプロリン (Hyp)に富む 糖タンパク質 (HRGP) であるエクステンシンやナス科レクチ 
as extensin and Solanaceae lectins. Extensin is a structural protein that is found in plant cell walls $(3,4)$. Solanaceae lectins contain an extensin-like domain and chitin-binding domains $(5,6)$. In addition to extensin and Solanaceae lectins, arabinogalactan-protein (AGP) is a member of HRGPs, in which hydroxyproline (Hyp) residues are glycosylated with type II arabinogalactans. Extensin and Solanaceae lectins contain repetitive Ser-Hyp $\mathrm{p}_{4}$ motifs with Hyp residues that are $O$-glycosylated with 1-4 arabinofuranosyl (Araf) residues with $\beta$-L-arabinofuranosyl linkages. The structures of $\mathrm{Ara}_{3}-\mathrm{Hyp}$ and $\mathrm{Ara}_{4}-\mathrm{Hyp}$, which are the major constituents of Hyp-linked $\beta$-Larabinofuranosides in dicotyledons (7), are Araf $\beta 1-2 A r a f \beta 1$ 2Araf $\beta$-Hyp and Araf $\alpha 1-3 A r a f \beta 1-2 A r a f \beta 1-2 A r a f \beta-H y p$, respectively $(8,9)$. However, despite the broad distribution of Hyp-linked $\beta$-L-arabinofuranosides in plant cells, degradative enzymes have not been identified yet.

Bifidobacteria are strictly anaerobic bacteria that are common in the lower intestinal microflora of humans and animals. Bifidobacterium longum is one of the major species of bifidobacteria and is frequently found both in the feces of both infants and adults. In 2002, genome sequence analysis of B. longum NCC2705 revealed 7 gene clusters, which are involved in the degradation of oligo- and polysaccharides (10). In particular, 4 of the 7 gene clusters contained 9 candidate genes for $\alpha$-L-arabinofuranosidase belonging to GH43 and 51 . Several reports have indicated that $B$. longum has the ability to grow on various non-digestible plant carbohydrate polymers containing $\alpha$-L-arabinofuranosyl linkages, e.g., arabinoxylan, arabinogalactan, and arabinan (11-13). The presence of degradative enzymes for plant carbohydrates may reflect the superior ability of B. longum to adapt to the intestinal environment.

In this review, we describe the process of the discovery, the functional features of enzymes for Hyp-linked $\beta$-L-arabinofuranosides, and the predicted metabolic pathway in $B$. longum. Furthermore, we discuss a carbon-utilization strategy of B. longum targeting plant glycoproteins in the gastrointestinal tract.

\section{B. Exploration of a Novel Glycoside Hydrolase in a Hypothetical Protein}

Because many genome sequences have been disclosed, cloning techniques based on genome sequence information are important tools for characterizing hypothetical proteins. In 2005, we cloned and characterized a novel GH101 endo$\alpha-N$-acetylgalactosaminidase, which is a degradative enzyme for core-1 mucin-type $O$-glycans, from the type strain of B. longum, JCM 1217, on the basis of the sequence of a hypothetical protein (BL0464) from B. longum NCC2705 (14). BL0464 is an enzyme bound to the bifidobacterial surface, and contains C-terminal FIVAR regions, which are
ンの糖鎖に含まれている。エクステンシンは植物細胞壁に存 在する構造タンパク質であり (3、4)、ナス科レクチンはエクス テンシン様ドメインと複数のキチン結合領域で構成された糖 タンパク質である $(5,6)$ 。エクステンシンやナス科レクチン に加えて、II型 arabinogalactan が Hyp に結合した糖鎖を有 する arabinogalactan-protein (AGP) も HRGP のメンバーであ る。エクステンシンやナス科レクチンは Ser-Hyp ${ }_{4}$ の繰り返し 構造を有して扮り、その Hyp 残基に $\beta$ - アラビノオリゴ糖鎖が 結合している。その糖鎖構造は $\beta$-Araf で構成された Araf $\beta 1$ -

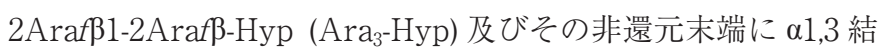
合でArafが付加された $\mathrm{Ara}_{4}$-Hyp であり (8、9)、 $\mathrm{Ara}_{3}-\mathrm{Hyp}$ と $\mathrm{Ara}_{4}-\mathrm{Hyp}$ が双子葉植物に打ける $\beta$ - アラビノオリゴ糖鎖の主要 な構造である (7)。しかしながら、植物に扔ける $\beta$ - アラビノオ リゴ糖鎖の広範囲に及ぶ分布にもかかわらず、その分解酵素 の存在は全く知られていなかった。

ビフィズス菌はヒトや動物の大腸に棲息する偏性嫌気 性菌である。その中でも、Bifidobacterium longum は子供 から大人まで全ての年齢層の翼便から分離される主要なビ フィズス菌の一つである。2002 年にB. longum NCC2705の ゲノム配列情報が開示され、オリゴ糖や多糖の分解に関わる 7 つの遺伝子クラスターの存在が予想された (10)。特に、7 つのクラスターの内 4 つは GH43 や GH51 に属す 9 つの $\alpha$-Larabinofuranosidase 候補遺伝子が含まれていた。B. longum は、 $\alpha$-L-Araf 含有多糖である arabinoxylan や arabinogalactan や arabinan 等の様々な難消化性多糖に対して資化性を示すこ とが報告されている(11-13)。植物多糖に対する分解酵素の存 在は、腸内環境に適応したB. longumの優れた能力を反映し ているものと考えられる。

本総説では、我々が $B$. longum から $\beta$ - アラビノオリゴ糖 鎖分解酵素群を発見した経緯、各酵素の機能特性及び、予想 される代謝経路について述べる。さらに、腸内環境において 植物糖タンパク質を炭素源として利用するB. longum の生存 戦略について考察する。

\section{B. 仮想タンパク質からの新規糖質分解酵素の探索 \\ 多くのゲノム配列が明らかにされている現在、ゲノム配列} 情報を利用したクローニング手法は仮想タンパク質の機能解 析のための重要なッールである。2005 年に我々は、B. longum NCC2705 の仮想タンパク質 BL0464 の配列情報を基に、基準 株である B. longum JCM1217 からのムチン型糖鎖分解酵素 GH101 endo- $\alpha$ - $N$-acetylgalactosaminidase の同定に初めて成功 した(14)。BL0464 はビフィズス菌表層に局在する酵素であり、 その C 末端にFIVAR 領域(細菌の細胞壁関連タンパク質に 保存された未同定の糖結合領域 (15)) と膜アンカリング領域を 
(A)

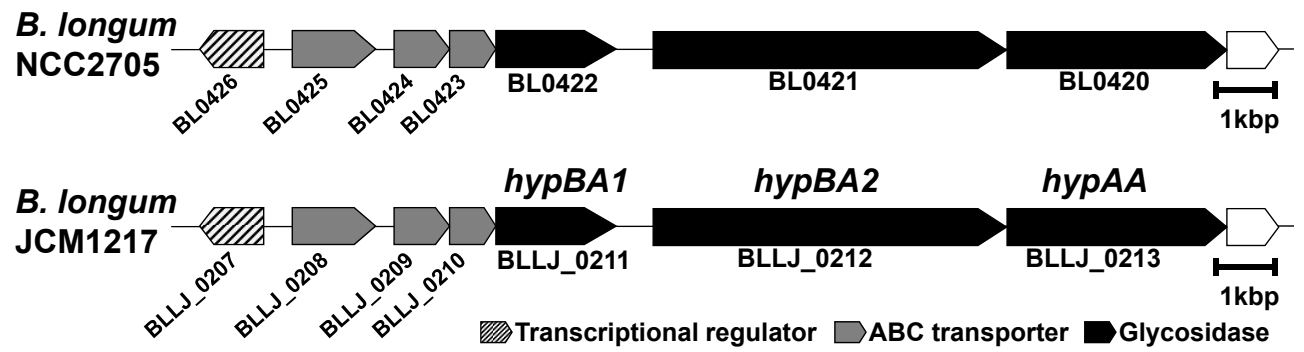

(B)

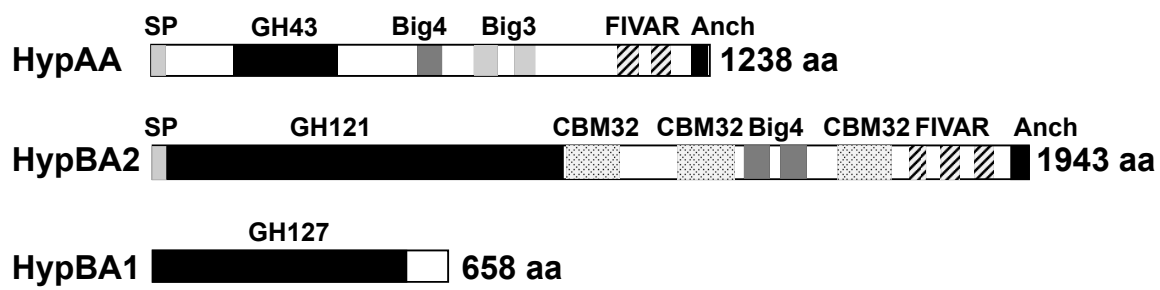

Fig. 1. Degradative enzymes for Hyp-linked $\beta$-L-arabinofuranosides in Bifidobacterium longum. A, Gene cluster involved in the degradation of Hyp-linked $\beta$-L-arabinofuranosides. The locus tags and gene names of B. longum JCM1217 and NCC2705 are shown. B, Structural motives of the enzymes. The name of their motives and their amino acid lengths are shown. SP, signal peptide; Anch, membrane-anchoring region; Big3, Bacterial Ig-like domain (group 3); Big4, Bacterial Ig-like domain (group 4); FIVAR, uncharacterized sugar-binding domain; CBM32, carbohydrate-binding module family 32.

uncharacterized sugar-binding domain conserved in bacterial cell wall-associated proteins (15), and a membrane-anchoring region. Similar to BL0464, BL0420 and BL0421 also contain $\mathrm{C}$-terminal FIVAR and membrane-anchoring regions (Fig. 1). Schell et al. (10) predicted that BL0420 and BL0421 may be involved in binding or degrading xylan or hemicellulose. While BL0420 contains a GH43 conserved region, which includes xylosidases and $\alpha$-L-arabinofuranosidases, BL0421 contains no conserved region to any known glycoside hydrolase in the $\mathrm{N}$-terminus. We hypothesized that BL0421 is a novel glycoside hydrolase that coordinately degrades arabinan or xylan with BL0420 on the bifidobacterial surface. Therefore, we cloned the hypBA2 gene (BLLJ_0212) of a BL0421 homolog from B. longum JCM 1217, as shown in Fig. 1A, and explored potential substrates for the recombinant protein. In various synthetic $p$ NP substrates and natural polysaccharides, the enzyme was able to release disaccharide composed of L-arabinose from commercial arabinan and debranched arabinan (16). However, NMR analysis revealed that the structure of the product was Araf $\beta 1-2 \operatorname{Araf}\left(\beta-\mathrm{Ara}_{2}\right)$ with $\beta$-anomeric configuration, which has never been found in arabinan. Only small amounts of the liberated saccharides (approximately $0.02 \%$ ) were produced from commercially available sugar beet arabinan. Therefore, we assumed that the $\beta$ - $\mathrm{Ara}_{2}$ residue was a contaminant from plant tissues. A literature search for oligosaccharides that contain the Araf $\beta$ 1-2Araf moiety suggested that Hyp-linked $\beta$-L-
含んでいた。我々は新たに、BL0464 と同様にC末端FIVAR 領域と膜アンカリング領域を有していた BL0420 と BL0421に 注目した(図 1)。Schell ら (10) は、BL0420 と BL0421 がxylan もしくは hemicellulose に対する結合や分解に関わるタンパク 質と予想していた。BL0420 は $\mathrm{N}$ 末端側にxylosidase や $\alpha$-Larabinofuranosidase が含まれる GH43 保存領域を有していた が、BL0421 は既知の糖質分解酵素の保存領域を持たない機能 未知タンパク質であった。このため、我々は BL0421 がビフィ ズス菌表層にて BL0420 と共に arabinan やxylan を分解する 新規糖質分解酵素であると予想した。そこで、図 $1 \mathrm{~A} に$ に示す ようにBL0421 のホモログである hypBA2 遺伝子 (BLLJ_0212) をB. longum JCM1217 からクローニングし、大腸菌で発現さ せた組換えタンパク質を用いて基質の探索を行った。数多く の $p \mathrm{NP}$ 基質や多糖類を基質として用いて酵素反応を行った 結果、L-arabinose で構成された二糖が市販のアラビナン及び 脱分岐アラビナンから遊離された (16)。しかし、NMR 解析に より判明したその構造は、アラビナンでは報告されていない 及-アノマー構造を有する Araf $\beta 1-2 A r a f\left(\beta-\mathrm{Ara}_{2}\right)$ であった。市 販のシュガービートアラビナンから得られた遊離糖の収率は 0.02\%程度であったことから、 $\beta-\mathrm{Ara}_{2}$ はアラビナンに混入した 植物組織に由来すると予想された。そこで、遊離糖の A raf $\beta 1$ $2 \mathrm{Araf}$ 構造を基に文献検索を行った結果、ナス科レクチンやエ 
Table I. Action of the enzymes on various substrates.

\begin{tabular}{lccc}
\hline Substrates & HypAA & HypBA2 & HypBA1 \\
\hline Ara $_{4}$-Hyp & + & - & - \\
Ara $_{3}$-Hyp & - & + & + \\
Ara $_{2}$-Hyp & - & - & + \\
Ara-Hyp & - & - & + \\
B-Ara $_{2}$ & - & - & + \\
Potato lectin & + & + & - \\
Extensin & + & + & - \\
\hline
\end{tabular}

+ , hydrolyzed ; -, not hydrolyzed

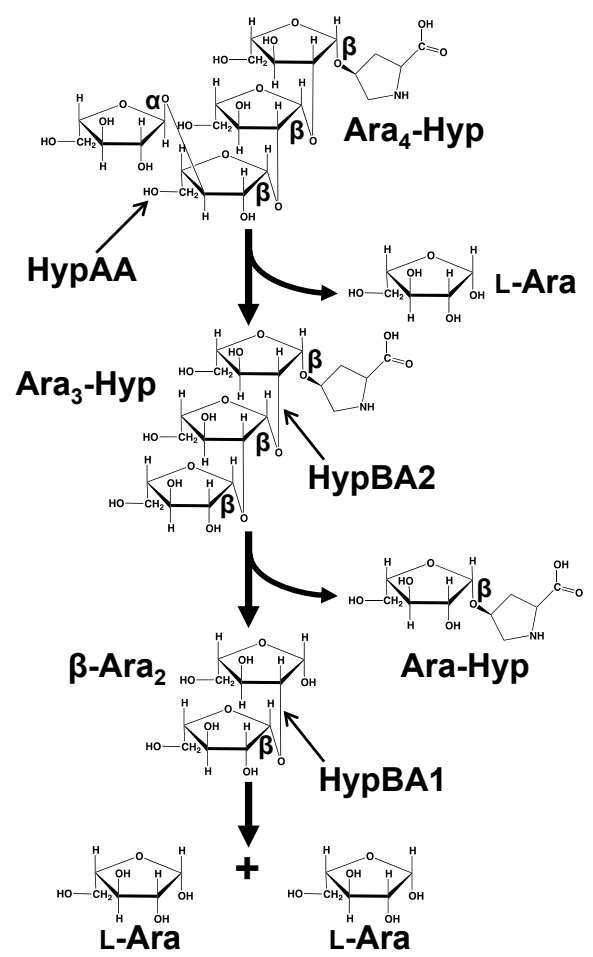

Fig. 2. Schematic representation of the hydrolysis of $\mathrm{Ara}_{4}-\mathrm{Hyp}$ by HypAA, HypBA2, and HypBA1. The thin arrows indicate the cleavage sites for the enzymes. arabinofuranosides from Solanaceae lectins and extensin act as substrates for HypBA2.

\section{Characterization of $\beta$-L-Arabinobiosidase Using Hyp- Linked $\beta$-L-Arabinofuranosides}

Substrate preparation is the most important part in the characterization of enzymes. Potato lectin and carrot extensin containing Hyp-linked $\beta$-L-arabinofuranosides were prepared as described previously $(17,18)$. Furthermore, Hyp-linked $\beta$-Larabinofuranosides were easily prepared by using an alkaline hydrolysis procedure (16). However, the artificial cis form of Hyp-linked $O$-glycans was isomerized from the natural trans form by alkaline hydrolysis (19), and the cis and trans conformers were easily separated on an ODS column by fluorescence labeling of Hyp with dansyl chloride (16).

HypBA2 liberated $\beta$-Ara ${ }_{2}$ from unmodified $\mathrm{Ara}_{3}-$ Hyp but not $\mathrm{Ara}_{4}-\mathrm{Hyp}$ or Araf $\beta 1-2 \mathrm{Araf} \beta$-Hyp ( $\mathrm{Ara}_{2}-$ Hyp) (Table I, Fig. 2). Hence, we designated HypB A2 as $\beta$-L-arabinobiosidase (16). The enzyme exhibited transglycosylation activity toward 1-alkanols with retention of the anomeric configuration. This is the first report of an enzyme that hydrolyzes $\beta$-L-arabinofuranosides, which defines a new CAZy family of glycoside hydrolases, GH121.

Thus far, Hyp-linked arabinofuranosides in plants have been analyzed by alkaline hydrolysis and column chromatography. Recently, extensin has been identified as the essential factor in root hair growth (20). HypBA2 has strict substrate specificity for $\mathrm{Ara}_{3}-\mathrm{Hyp}$, and directly liberated $\beta-\mathrm{Ara}_{2}$
クステンシンに含まれる $\beta$-アラビノオリゴ糖鎖が HypBA2 の 真の基質候補として浮上した。

C. Hyp 結合型 $\boldsymbol{\beta}$-アラビノオリゴ糖鎖を用いた $\boldsymbol{\beta}$-Larabinobiosidase の性質決定

酵素の性質決定を行うためには基質の調製が欠かせない。 幸い、 $\beta$-アラビノオリゴ糖鎖を含有するポテトレクチンやニ ンジンエクステンシンの調製法は確立されていた (17、18)。ま た、 $\beta$-アラビノオリゴ糖鎖はアルカリ分解を用いることで簡 単に調製することができた (16)。 $\beta-$ アラビノオリゴ糖鎖の Hyp 残基はアルカリ分解により天然型の trans 型が一部 cis 型に異 性化されたが (19)、ダンシルクロリドを用いた Hyp の蛍光ラ ベル化により、cis-trans 異性体は ODS カラムで簡単に分離す ることができた (16)。

HypBA2 は、 $\mathrm{Ara}_{3}$-Hyp に作用し $\beta$ - $\mathrm{Ara}_{2}$ を遊離したが、 $\mathrm{Ara}_{4}$-Hyp や Araf $\beta 1-2 \mathrm{Araf} \beta$-Hyp (Ara 2 -Hyp) には作用しなかっ た(表I、図 2)。このため、HypBA2 を $\beta$-L-arabinobiosidase と 命名した(16)。本酵素はアルコールに対して糖転移活性を示す アノマー保持型酵素であった。本酵素は $\beta$-アラビノオリゴ糖 鎖の $\beta$-L-アラビノフラノシド結合を切断する初めての酵素と して、CAZy 糖質分解酵素ファミリー GH121 に新たに登録さ れた。

これまで、植物に含まれる $\beta$-アラビノオリゴ糖鎖はアル カリ加水分解とカラムクロマトグラフィーを用いて分析され てきた。最近、エクステンシンは根毛の伸長に必須の因子と して注目されている(20)。HypBA2 はエクステンシンやポテト レクチンに直接作用し、 $\mathrm{Ara}_{3}-\mathrm{Hyp}$ 特異的に $\beta-\mathrm{Ara}_{2}$ を遊離させ 
from carrot extensin and potato lectin (Table I). Therefore, the enzyme can be used to develop a simpler technique to detect and study the role of $\beta$-L-arabinofuranosides in plant.

\section{Identification of a Novel $\boldsymbol{\beta}$-L-Arabinofuranosidase by Expression Analysis of the hypBA1 Gene}

Because HypBA2-released $\beta$-Ara 2 should be hydrolyzed by its own enzyme for assimilation, we predicted that $B$. longum has a gene encoding $\beta$-L-arabinofuranosidase. The genome sequence of our research strain, B. longum JCM1217, was disclosed in 2011 (21). The hypBAl gene (BLLJ_0211), which neighbors the hypBA2 gene (BLLJ_0212), contains a Pfam DUF 1680 domain (Fig. 1). The DUF1680 family (PF07944) is annotated as putative glycosyl hydrolase of unknown function. This family has 943 members distributed among 423 species of bacteria, actinomycetes, fungi, and plants. Therefore, we cloned the hypBAl gene from B. longum JCM 1217 and characterized the recombinant protein as a novel $\beta$-L-arabinofuranosidase (22). The enzyme released L-arabinose from $\beta$-Ara ${ }_{2}$, Ara-Hyp, Ara $_{2}-$ Hyp and Ara $_{3}$-Hyp, but not from carrot extensin and potato lectin (Table I, Fig. 2). The enzyme also exhibited transglycosylation activity toward 1 -alkanols with retention of the anomeric configuration. Because the amino acid sequence of HypBA1 lacks both a secretory signal and a membrane-anchoring region (Fig. 1B), HypBA1 is thought to be an intracellular enzyme that degrades HypBA2-released $\beta$-Ara ${ }_{2}$. This is the first characterization of a DUF1680 family member, which defines a new CAZy family of glycoside hydrolases, GH127. The DUF1680 family members are widely distributed in bifidobacteria. In particular, B. longum JCM 1217 encodes 4 members of the DUF1680 family (BLLJ_0211, BLLJ_1826, BLLJ_1848, and BLLJ_0089). Terminal $\beta$-L-arabinofuranosyl residues have been found in AGP from a pollen (23), rhamnogalacturonanII (24-26), olive arabinan (27), arabinoglucan from Angelica sinensis (28), and tomato arabinoxyloglucan (29). Furthermore, $\beta$-L-arabinofuranosyl residues were found in yessotoxin from dinoflagellates $(30,31)$. Therefore, DUF1680 family members are thought to play a role in the effective degradation of several $\beta$-L-arabinofuranosyl residues in biopolymers as well as Hyp-linked $\beta$-L-arabinofuranosides.

\section{E. Identification of Ara 4 -Hyp-specific $\alpha-L$ - Arabinofuranosidase by Expression Analysis of the hypAA gene}

$\mathrm{Ara}_{4}$-Hyp as well as $\mathrm{Ara}_{3}$-Hyp are the major Hyp-linked $\beta$-L-arabinofuranosides in the dicotyledon. In the cell walls of dicot plants, $\mathrm{Ara}_{4}-\mathrm{Hyp}$ accounts for $33 \%-75 \%$ of the total Hyp residues (7). With regard to potato lectin, Ara ${ }_{4}-\mathrm{Hyp}$ accounts for $47 \%$ of the total Hyp residues (32). Since HypBA2 cannot hydrolyze $\mathrm{Ara}_{4}$-Hyp, $\alpha$-L-arabinofuranosidase is required for
る能力がある (表 I)。このため、本酵素を利用することで植物 に含まれる $\beta$ - アラビノオリゴ糖鎖の存在を簡単に調べること ができると考えられる。

\section{D. hypBA1 遺伝子の発現解析による $\boldsymbol{\beta}$-L-arabinofuranosidase の同定}

HypBA2により遊離された $\beta-\mathrm{Ara}_{2}$ が $B$. longum で資化さ れるためには、自身の酵素によりL-arabinoseにまで分解さ れる必要がある。このため、我々はその分解酵素である $\beta-L-$ arabinofuranosidase がB. longum にコードされていると予想 した。幸い、我々が解析対象としているB. longum JCM1217 のゲノム情報が 2011 年に開示され (21)、詳細な解析が可能と なった。その候補遺伝子となったhypBA1 遺伝子 (BLLJ_0211) は、hypBA2 遺伝子(BLLJ_0212) に隣接しており、Pfam DUF1680 ドメインをコードしていた (図 1)。DUF1680 ファミ リー (PF07944) は機能未知の糖質分解酵素であると推定され ており、細菌・放線菌・糸状菌・植物など 423 種に保存されて いる 943 遺伝子が登録されている。そこで、hypBA1 遺伝子の クローニングと組換え酵素の性質決定を行った結果、HypBA1 が新規 $\beta$-L-arabinofuranosidaseであることを明らかにした (22)。 本酵素は L-arabinose を $\beta$-Ara 2 、Ara-Hyp、Ara 2 -Hyp、Ara Hypから遊離したが、ポテトレクチンやエクステンシンから L-arabinose を遊離することはできなかった(表I、図 2)。また、 HypBA2 と同様に本酵素もアルコールに対して糖転移活性を 示すアノマー保持型酵素であった。HypBA1 が有する保存領 域はDUF1680 ドメインだけであり、シグナルペプチドや膜ア ンカリング領域を有していない(図 1B)。このため、HypBA1 はHypBA2によって遊離された $\beta$ - $\mathrm{Ara}_{2}$ をL-arabinose に分解 する菌体内酵素であると予想された。HypBA1 はDUF1680 ファミリーにおいて初めて性質決定された酵素であり、新規 糖質分解酵素ファミリーGH127に登録された。DUF1680 ファ ミリーのメンバーはビフィズス菌のほとんど全ての菌種で保 存されているが、特にB. longum JCM1217 は多くの DUF1680 メンバー (BLLJ_0211, BLLJ_1826, BLLJ_1848, BLLJ_0089) を 有している。多糖の非還元末端に存在する $\beta$-L-Araf 残基は、 花粉由来の AGP (23)、各種 rhamnogalacturonan-II (24-26)、 オリーブ由来の arabinan (27)、トウキ由来の arabinoglucan (28) やトマト由来の arabinoxyloglucan (29) でその存在が報告され ている。さらに、 $\beta$-L-Araf 残基は渦鞭毛藻類由来の配糖体であ

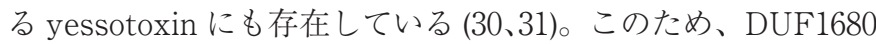
ファミリーには、Hyp 結合型 $\beta$-アラビノオリゴ糖鎖だけでな く、多彩な $\beta-\mathrm{L}-$ アラビノフラノシド結合を切断する酵素が含 まれていると考えられる。

E. hypAA 遺伝子の発現解析による $\mathrm{Ara}_{4}-\mathrm{Hyp}$ 特異的 $\boldsymbol{\alpha}$-Larabinofuranosidase $の$ 同定

$\mathrm{Ara}_{4}$-Hyp は $\mathrm{Ara}_{3}$-Hyp と同様に双子葉植物における主要 な Hyp 結合型 $\beta$ - アラビノオリゴ糖鎖である。双子葉植物の 細胞壁の $\mathrm{Ara}_{4}$-Hyp の割合は Hyp 残基の 33\% から 75\% であ り (7)、ポテトレクチンの $\mathrm{Ara}_{4}$-Hyp の割合は Hyp 残基の $47 \%$ と報告されている (32)。HypBA2 は $\mathrm{Ara}_{3}$-Hyp 特異的であるた め、 $\mathrm{Ara}_{4}-\mathrm{Hyp}$ を切断するためには、まず非還元末端に存在す る $\alpha$-L-Araf 残基を $\alpha$-L-arabinofuranosidase で切断する必要が ある。hypBA2 遺伝子と遺伝子クラスターを形成する hyp $A A$ 


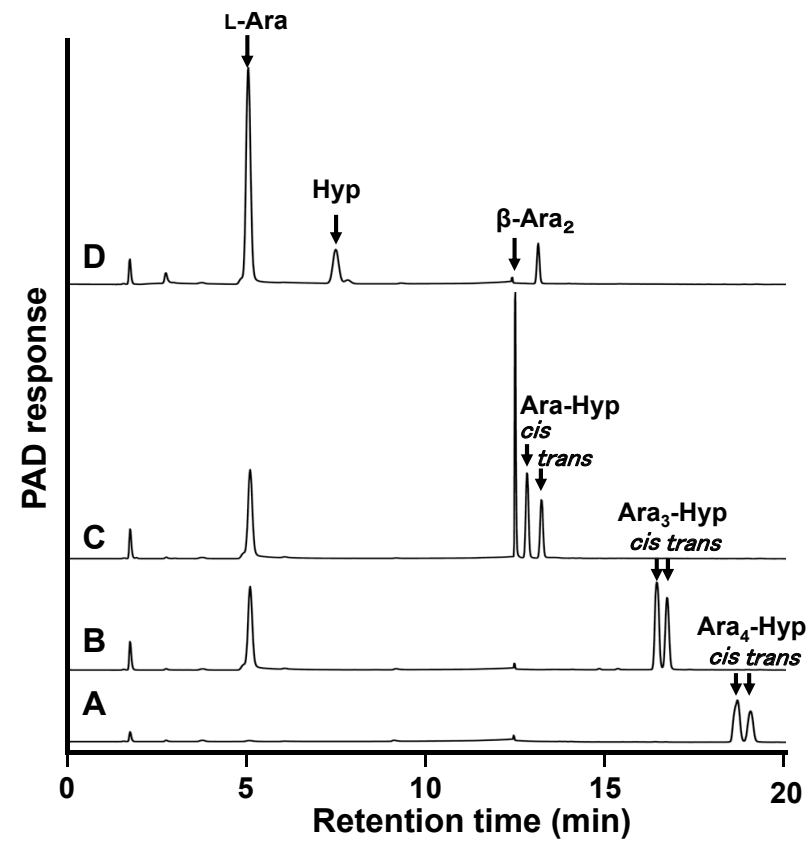

effective degradation of $\beta$-L-arabinofuranosides. Since the hypAA gene (BLLJ_0213) containing a GH43 domain forms a gene cluster with the hypBA2 gene (Fig.1), we cloned the hypAA gene and characterized the recombinant protein as $\alpha-\mathrm{L}-$ arabinofuranosidase (unpublished results). HypAA specifically degraded $\mathrm{Ara}_{4}$-Hyp to $\mathrm{Ara}_{3}$-Hyp and L-arabinose (Table I, Fig.2). Furthermore, the enzyme hydrolyzed Araf $\alpha 1-3$ Araf disaccharide, but not Araf $\alpha 1-2 \mathrm{Ara} f$, Araf $\alpha 1-5 \mathrm{Ara} f$, or $p$ NP- $\alpha$ L-arabinofuranoside (unpublished results). Therefore, HypAA is a $\alpha 1-3$-specific $\alpha$-L-arabinofuranosidase, which recognizes the Araf $\alpha 1-3$ Ara $f$ structure of $\mathrm{Ara}_{4}$-Hyp. In addition, HypAA directly liberated L-arabinose from carrot extensin and potato lectin (Table I). Because HypAA contains a predicted signal peptide and a membrane-anchoring region (Fig.1B), the enzyme might be localized on the bifidobacterial surface and coordinately degrade $\mathrm{Ara}_{4}$-Hyp with HypBA2.

Next, we examined the synergistic effect of the enzymes on the degradation of Hyp-linked $\beta$-L-arabinofuranosides. Ara $_{4}$-Hyp was completely degraded in combination with HypAA, HypBA2 and HypBA1 (Fig.3). These enzymes coordinately degrade $\mathrm{Ara}_{4}$-Hyp to L-arabinose as summarized in Fig.2. Because these enzymes probably have to degrade very crowded $\beta$-L-arabinofuranosides on extensin, these enzymes may bind to extensin for subsequent degradation using C-terminal carbohydrate-binding module family 32, Bacterial Ig-like domains, and FIVAR regions (Fig.1B). The gene cluster containing hypAA, hypBA2, and hypBA1 was conserved in many strains of $B$. longum subsp. longum (JCM1217, NCC2705, BBMN68, F8, and KACC91563) and B. longum subsp. infantis (157F, ATCC55813, and
Fig. 3. Analysis of the products formed by combination of the enzymes. Ara ${ }_{4}$ Hyp was incubated without enzymes (A), with HypAA (B), with HypAA and HypBA2 (C), and with HypAA, HypBA2, and HypBA1 (D) at $30^{\circ} \mathrm{C}$ for $16 \mathrm{~h}$. The reaction products were analyzed by high-performance anion exchange chromatography equipped with a pulsed amperometric detector.

遺伝子 (BLLJ_0213) は、 $\alpha$-L-arabinofuranosidase をコードす ると予想された GH43 ドメインを有していた(図 1)。そこで、 hyp $A$ A 遺伝子のクローニングと組換え酵素の性質決定を行っ た結果、本酵素が $\alpha$-L-arabinofuranosidase であることを明ら かにした (未発表データ)。HypA は $\mathrm{Ara}_{4}$-Hyp 特異的に作 用し、L-arabinose と $\mathrm{Ara}_{3}-\mathrm{Hyp}$ に分解した(表I、図 2)。ま た、本酵素は $p$ NP- $\alpha$-L-arabinofuranoside に作用せず、Araf $\alpha 1$ 2Araf、Arafa1-3Araf、Arafa1-5Araf の中では Arafo1-3Araf だ けを切断することが確認された (未発表データ)。以上の結果、 HypAA は $\mathrm{Ara}_{4}$-Hyp の Arafal-3Araf 構造を認識して切断す る $\alpha$-L-arabinofuranosidase であることが明らかとなった。そ の上、HypAA はエクステンシンやポテトレクチンに直接作用 し、L-arabinose を遊離させることができた(表 I)。HypAA は シグナルペプチドや膜アンカリング領域を含んでいることか ら (図 1B)、ビフィズス菌の表層に局在し、HypBA2 と協力し て $\mathrm{Ara}_{4}$-Hyp を分解していると考えられる。

次に、我々は $\beta$ - アラビノオリゴ糖鎖分解酵素群の相乗 効果の検証を行った。HypAA、HypBA2、HypBA1を $\mathrm{Ara}_{4}$ Hyp に順次添加した結果、Ara - Hyp を完全にL-arabinose に 分解することができた (図 3 )。このため、Ara に示すような酵素群の協同作用により L-arabinose に分解さ れていると考えられる。これらの酵素はエクステンシン上の 密集した状態で存在する $\beta$-アラビノオリゴ糖鎖から糖を遊 離する必要があるため、図 $1 \mathrm{~B}$ に示した $\mathrm{C}$ 末端側の保存領域 (CBM32、Ig 様ドメイン、FIV AR 領域) の働きによりエクス テンシンに結合し、効率的な分解を行っていると考えられる。 hур $A A$ 、 hурBA2、hypBA1により構成された遺伝子クラス ターは多くのB. longum subsp. longum (JCM1217, NCC2705, BBMN68, F8, KACC91563) やB. longum subsp. infantis (157F, ATCC55813, CCUG52486) に保存されている。また、B. pseudocatenulatum は遺伝子クラスターを完全に保存し、B. 


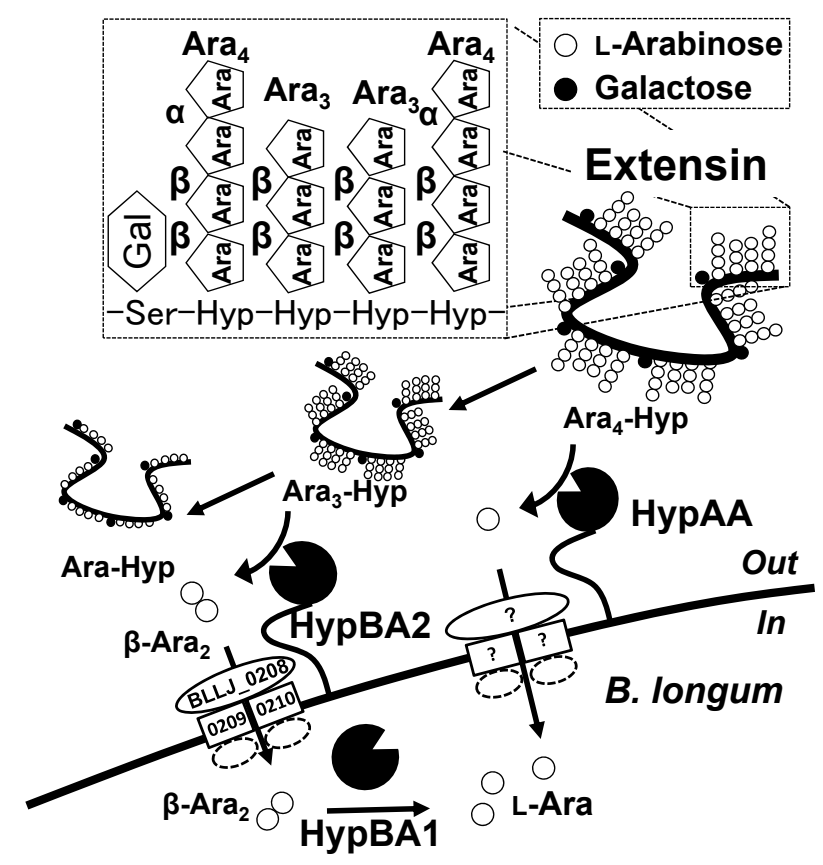

CCUG52486). The gene cluster was also conserved in $B$. pseudocatenulatum as well as in B. catenulatum and $B$. dentium, but in the latter 2 organisms, the sequence encoding HypAA was not conserved. In addition, the gene cluster was not found in other gut bacteria (e.g., Bacteroides, Salmonella, Clostridium, and Escherichia). Therefore, HRGPs containing $\beta$-L-arabinofuranosides are considered candidate prebiotics for bifidobacteria. Interestingly, the gene cluster was conserved in many species of plant-pathogenic Xanthomonas. These enzymes may be beneficial for plant infection via the degradation of extensin, which has a role in plant defense.

\section{F. Predicted Metabolic Pathway of $\beta$-L-Arabinofuranosides in B. longum}

$\beta$ - $\mathrm{Ara}_{2}$ in PYF medium was utilized as carbohydrate source by B. longum JCM 1217 but not by B. adolescentis JCM 1275 (22). Furthermore, enzymatic activities of HypAA and HypBA2 were found in B. longum whole cells grown in the presence of $\beta-\mathrm{Ara}_{2}$, and $\mathrm{HypBA} 1$ activity was also found in the cell lysate of B. longum. However, these activities were not detected in cultures grown in media containing glucose and L-arabinose. Interestingly, $B$. longum produced not only HypBA1 but also HypAA and HypBA2 by using $\beta-\mathrm{Ara}_{2}$ as carbohydrate source. The contiguous genes of hypBAl contain candidate genes for $\mathrm{ABC}$ transporter proteins (BLLJ_0208BLLJ_0210) and a LacI-type transcriptional regulator (BLLJ_0207) (Fig.1A). We expect that the expression of this gene cluster was induced by $\beta-\mathrm{Ara}_{2}$ in $B$. longum. Furthermore, we found that B. longum JCM 1217 utilized $\mathrm{Ara}_{4}$-Hyp and extensin as carbohydrate source (unpublished
Fig. 4. Schematic degradative pathway of $\beta-L-$ arabinofuranosides on extensin in Bifidobacterium longum.

catenulatum とB. dentium は HypBA2 と HypBA1 ホモログ を有している。一方、Bacteroides、Salmonella、Clostridium、 Escherichia 等のビフィズス菌以外の腸内細菌は、この遺伝子 クラスターを保持していない。このため、 $\beta$-アラビノオリゴ 糖鎖を有する HRGP は、大腸内に扔いてビフィズス菌だけに 利用されるプレバイオティクス候補になると考えられる。興 味深いことに、植物病原性を有するXanthomonas 属細菌の多 くはこの遺伝子クラスターを保存していた。これらの酵素は、 感染防御機能を有するエクステンシンを分解することで植物 感染に寄与しているものと考えられる。

\section{F. $\beta$ - アラビノオリゴ糖鎖の予想される分解代謝機構}

$\beta-\mathrm{Ara}_{2}$ を炭素源として添加したPYF培地を用いて $B$. longum JCM1217 及びB. adolescentis JCM1275を培養した 結果、B. longumでは良好な生育が確認されたのに対して、 B. adolescentisでは生育が確認されなかった (22)。さらに、 HypAA 及び HypBA2 の酵素活性が $\beta$ - Ara $_{2}$ 存在下で培養した B. longum の未破砕菌体から検出され、HypBA1 の酵素活性 が破砕菌体から検出された。な㧍、L-arabinose 及び glucose で培養したB. longum では酵素活性が検出されなかった。興 味深いことに、炭素源として $\beta-\mathrm{Ara}_{2}$ を用いることにより、 HypBA1 だけでなくHypAA 及びHypBA2 も生産された。本 酵素群をコードする遺伝子クラスターの隣には ABC 輸送体 (BLLJ_0208-BLLJ_0210) や LacI 型転写因子 (BLLJ_0207) の候 補遺伝子が含まれている(図1A)。このため、B. longum は $\beta-\mathrm{Ara}_{2}$ を用いてこの遺伝子クラスターの発現を誘導している と考えられる。さらに、我々はB. longum JCM1217 が Ara Hyp 及びエクステンシンを資化することも確認している ( 未 発表データ)。 
results).

Figure 4 shows the proposed metabolic pathway of $\beta$-L-arabinofuranosides in B. longum. First, $\beta$ - $\mathrm{Ara}_{2}$-inducible HypAA and HypBA2 are localized on the surface of the bacteria, and then, HypAA (BLLJ_0213) releases L-arabinose from extensin ( $\mathrm{Ara}_{4}-\mathrm{Hyp}$ to $\left.\mathrm{Ara}_{3}-\mathrm{Hyp}\right)$. Next, HypBA2 (BLLJ_0212) releases $\beta$-Ara ${ }_{2}$ from extensin ( Ara $_{3}-\mathrm{Hyp}$ to Ara-Hyp). Then, the released L-arabinose and $\beta$ - $\mathrm{Ara}_{2}$ are internalized into the bifidobacterial cell by an uncharacterized transport system and predicted $\mathrm{ABC}$ transporter proteins (BLLJ_0208-BLLJ_0210), respectively. Next, HypBA1 (BLLJ_0211) degrades $\beta$-Ara ${ }_{2}$ to L-arabinose. Furthermore, L-arabinose is metabolized to D-xylulose-5-phosphate by L-arabinose isomerase (BLLJ_0342), L-ribulokinase (BLLJ_0340), and L-ribulose 5-phosphate 4-epimerase (BLLJ_0341).

\section{G. Effects of Polysaccharides and HRGPs Containing L-Arabinose on the Growth of $B$. longum}

In 2011, Fukuda et al. (21) reported that B. longum has an advanced ability for fructose uptake and acetate production. The released acetate improved the intestinal defense mediated by epithelial cells and exerted a protective effect against $E$. coli O157:H7 infections in mice. Bifidobacteria metabolize glucose and fructose through a particular metabolic pathway, socalled bifid shunt, and form lactate and acetate via D-xylulose5-phosphate as major metabolites. L-Arabinose is a poorly absorbed sugar (33) and is scarcely metabolized in humans (34). Therefore, most of the L-arabinose is thought to utilize by intestinal bacteria. Many reports indicate that B. longum has the ability to grow in the presence of L-arabinose $(12,35-$ 37). B. longum JCM 1217 encodes a number of candidates for the $\alpha$-L-arabinofuranosidase gene, 11 members of GH43 gene family, and 4 members of GH51 gene family. Furthermore, the strain also encodes 4 members of the DUF1680 family, which are $\beta$-L-arabinofuranosidase candidates. Several $\alpha$ and $\beta$-L-arabinofuranoside degradative enzymes in B. longum might be involved in L-arabinose acquisition from plant polysaccharides and HRGPs in the large intestine. In fact, gum arabic containing type-II arabinogalactan and AGP are fermented by almost all strains of B. longum, but not by the other 28 species of bifidobacteria (11). B. longum, which is one of the predominant bifidobacterial species in the large intestine, is thought to contribute to maintaining the health of the large intestine by releasing acetate through metabolism of plant polysaccharides and HRGPs.

\section{H. Future Prospects}

Among bifidobacterial species, B. longum may have a superior ability for metabolizing plant polysaccharides and HRGPs containing L-arabinose. Many degradative enzymes
これらの結果から予想された $\beta$-アラビノオリゴ糖鎖の 分解代謝機構を図 4 に示す。まず、 $\beta-\mathrm{Ara}_{2}$ により誘導生産 されたHypAA と HypBA2 は菌体表層に局在し、HypAA (BLLJ_0213) がエクステンシンから L-arabinose を遊離させ る $\left(\mathrm{Ara}_{4}\right.$-Hyp から $\mathrm{Ara}_{3}$-Hyp)。次に、HypBA2 (BLLJ_0212) が $\beta$ - $\mathrm{Ara}_{2}$ を遊離させる $\left(\mathrm{Ara}_{3}-\mathrm{Hyp}\right.$ から Ara-Hyp)。そして、遊 離されたL-arabinose は未知の糖輸送体によって菌体内に取 り込まれ、 $\beta-\mathrm{Ara}_{2}$ は ABC 輸送体 (BLLJ_0208-BLLJ_0210)に よって取り达まれる。その後、 $\beta-\mathrm{Ara}_{2}$ は菌体内酵素である HypBA1 (BLLJ_0211)の作用を受けて L-arabinose に分解され る。さらに、L-arabinose は L-arabinose isomerase (BLLJ_0342)、 L-ribulokinase (BLLJ_0340)、L-ribulose 5-phosphate 4-epimerase (BLLJ_0341) で構成される L-arabinose 代謝経路を 経て D-xylulose-5-phosphate に代謝される。

\section{G. B. longum の増殖に及ぼす L-arabinose を含む多糖や HRGP} の効果

2011 年に福田ら (21) は、fructoseに対する高い取り込 み能力を有するB. longum が酢酸を多量に産生し、その酢酸 により腸粘膜上皮の抵抗力が増強され、マウスを腸管出血 性大腸菌 O157:H7 による感染死から守っていることを報告 した。ビフィズス菌はビフィズス経路と呼ばれる特有の代謝 経路を用いて、glucose や fructose を D-xylulose-5-phosphate を経て乳酸と酢酸に分解している。ヒトに消化吸収される これらの糖質と異なり、L-arabinose は難吸収性の糖質であ り (33)、吸収されてもヒトではほとんど代謝されることはな い(34)。このため、その大部分は腸内細菌によって利用され ていると考えられる。B. longumの L-arabinose に対する資化 性は数多く報告されている (12、35-37)。B. longum JCM 1217 は、 $\alpha$-L-arabinofuranosidase と予想される 11 遺伝子の GH43 と 4 遺伝子の GH51 をコードしている。さらにこの株は、 $\beta-\mathrm{L}$ arabinofuranosidase と予想されるDUF1680 ファミリーを4 遺伝子コードしている。このため、B. longum は、 $\alpha$-Araf だ けでなく $\beta$-Araf 結合を切断する様々な酵素を使うことで、植 物多糖や HRGP から L-arabinose を獲得していると考えられ る。実際に、ビフィズス菌 29 種の中でB. longum だけがII 型 arabinogalactan や AGP が含まれるアラビアガムを資化す ることができる $(11) 。 大$ 腸における優勢菌種の一つである $B$. longum は、植物多糖や HRGP を分解代謝することにより酢酸 を放出し、大腸の健全性の保持に貢献していると考えられる。

\section{H. 展 望}

各種ビフィズス菌の中でも特にB. longum は L-arabinose を含有する植物多糖や HRGP を分解代謝する高い能力を有し ている。HRGPの主要なメンバーの一つである AGP の資化 
will be required for the fermentation of AGP, which is a major member of HRGPs. However, these enzymes are not clearly identified in B. longum. In our future studies, we plan to analyze degradative enzymes for AGP and clarify the importance of HRGPs, which act as prebiotics glycoproteins for B. longum.

\section{Acknowledgments}

We thank the collaborators for their help in measuring the NMR spectra and providing the substrates. This work was supported in part by JSPS KAKENHI Grant Number 22780094.
のためには多くの分解酵素が必要と考えられる。しかし、B. longum が生産する A GP 酵素群は明らかになっていない。今 後は、 $\beta$ - アラビノオリゴ糖鎖分解酵素群に加えて A GP 分解酵 素群の解析を行うことで、B. longum を選択的に増やすプレバ イオティクス糖タンパク質である HRGP の重要性を明らかに したいと考えている。

謝辞

NMR 解析のサポートや基質の提供をして頂きました共同 研究者の皆様に感謝致します。本稿記載の研究の一部はJSPS 科研費 22780094 の助成により実施しました。

\section{References}

1. Kosugi, A., Murashima, K., and Doi, R. H. (2002) J. Bacteriol. 184, 6859-6865.

2. Ichinose, H., Fujimoto, Z., Honda, M., Harazono, K., Nishimoto, Y., Uzura, A., and Kaneko, S. (2009) J. Biol. Chem. $284,25097-25106$.

3. Showalter, A. M. (1993) Plant Cell 5, 9-23.

4. Kieliszewski, M. J., and Lamport, D. T. A. (1994) Plant J. 5, 157-172.

5. Oguri, S., Amano, K., Nakashita, H., Nagata, Y., and Momonoki, Y. S. (2008) Biosci. Biotechnol. Biochem. 72, $2640-2650$.

6. Van Damme, E. J. M., Barre, A., Rougé, P., and Peumans, W. J. (2004) Plant J. 37, 34-45.

7. Lamport, D. T. A., and Miller, D. H. (1971) Plant Physiol. 48, 454-456.

8. Akiyama, Y., Mori, M., and Kato, K. (1980) Agric. Biol. Chem. 44, 2487-2489.

9. Ashford, D., Desai, N. N., Allen, A. K., Neuberger, A., O'Neill, M. A., and Selvendran, R. R. (1982) Biochem. J. 201, $199-208$.

10. Schell, M. A., Karmirantzou, M., Snel, B., Vilanova, D., Berger, B., Pessi, G., Zwahlen, M. C., Desiere, F., Bork, P., Delley, M., Pridmore, R. D., and Arigoni, F. (2002) Proc. Natl. Acad. Sci. USA 99, 14422-14427.

11. Crociani, F., Alessandrini, A., Mucci, M. M., and Biavati, B. (1994) Int. J. Food Microbiol. 24, 199-210.

12. Suzuki, Y., Tanaka, K., Amano, T., Asakura, T., and Muramatsu, N. (2004) J. Jpn. Soc. Hort. Sci. 73, 574-579.

13. Van Laere, K. M., Hartemink, R., Bosveld, M., Schols, H. A., and Voragen, A. G. (2000) J. Agric. Food Chem. 48, $1644-1652$.

14. Fujita, K., Oura, F., Nagamine, N., Katayama, T., Hiratake, J., Sakata, K., Kumagai, H., and Yamamoto, K. (2005) J. Biol. Chem. 280, 37415-37422.

15. Komatsuzawa, H., Ohta, K., Sugai, M., Fujiwara, T., Glanzmann, P., Berger Bachi, B., and Suginaka, H. (2000) J. Antimicrob. Chemother. 45, 421-431.

16. Fujita, K., Sakamoto, S., Ono, Y., Wakao, M., Suda, Y., Kitahara, K., and Suganuma, T. (2011) J. Biol. Chem. $286,5143-5150$.

17. Ciopraga, J., Angstrom, J., Bergstrom, J., Larsson, T., Karlsson, N., Motas, C., Gozia, O., and Teneberg, S. (2000) J. Biochem. 128, 855867.

18. Magliano, T. M. A., and Casal, J. J. (1998) J. Exp. Bot. 49, 1491-1499.

19. Bollig, K., Lamshöft, M., Schweimer, K., Marner, F. J., Budzikiewicz, H., and Waffenschmidt, S. (2007) Carbohydr. Res. 342, 25572566.

20. Velasquez, S. M., Ricardi, M. M., Dorosz, J. G., Fernandez, P. V., Nadra, A. D., Pol-Fachin, L., Egelund, J., Gille, S., Harholt, J., Ciancia, M., Verli, H., Pauly, M., Bacic, A., Olsen, C. E., Ulvskov, P., Petersen, B. L., Somerville, C., Iusem, N. D., and Estevez, J. M. (2011) Science 332, 1401-1403.

21. Fukuda, S., Toh, H., Hase, K., Oshima, K., Nakanishi, Y., Yoshimura, K., Tobe, T., Clarke, J. M., Topping, D. L., Suzuki, T., Taylor, T. D., Itoh, K., Kikuchi, J., Morita, H., Hattori, M., and Ohno, H. (2011) Nature 469, 543-547.

22. Fujita, K., Takashi, Y., Obuchi, E., Kitahara, K., and Suganuma, T. (2011) J. Biol. Chem. 286, 38079-38085.

23. Brecker, L., Wicklein, D., Moll, H., Fuchs, E. C., Becker, W. M., and Petersen, A. (2005) Carbohydr. Res. 340, 657-663.

24. Mohnen, D. (2008) Curr. Opin. Plant Biol. 11, 266-277.

25. Pérez, S., Rodríguez-Carvajal, M. A., and Doco, T. (2003) Biochimie 85, 109-121.

26. Whitcombe, A. J., O'Neill, M. A., Steffan, W., Albersheim, P., and Darvill, A. G. (1995) Carbohydr. Res. 271, 15-29.

27. Cardoso, S. M., Silva, A. M., and Coimbra, M. A. (2002) Carbohydr. Res. 337, 917-924.

28. Cao, W., Li, X. Q., Liu, L., Yang, T. H., Li, C., Fan, H. T., Jia, M., Lu, Z. G., and Mei, Q. B. (2006) Carbohydr. Polym. 66, 149-159.

29. York, W. S., Kumar Kolli, V. S., Orlando, R., Albersheim, P., and Darvill, A. G. (1996) Carbohydr. Res. 285, 99-128.

30. Konishi, M., Yang, X., Li, B., Fairchild, C. R., and Shimizu, Y. (2004) J. Nat. Prod. 67, 1309-1313.

31. Souto, M. L., Fernández, J. J., Franco, J. M., Paz, B., Gil, L. V., and Norte, M. (2005) J. Nat. Prod. 68, 420-422.

32. Kieliszewski, M. J., Showalter, A. M., and Leykam, J. F. (1994) Plant J. 5, 849-861.

33. Schutte, J. B., de Jong, J., van Weerden, E. J., and Tamminga, S. (1992) Br. J. Nutr. 68, 195-207.

34. Segal, S., and Foley, J. B. (1959) J. Clin. Invest. 38, 407-413.

35. Biavati, B., Scardovi, V., and Moore, W. E. C. (1982) Int. J. Syst. Bacteriol. 32, 358-373.

36. Sakata, S., Kitahara, M., Sakamoto, M., Hayashi, H., Fukuyama, M., and Benno, Y. (2002) Int. J. Syst. Evol. Microbiol. 52, $1945-1951$.

37. Roy, D., and Ward, P. (1990) J. Appl. Bacteriol. 69, 739-749. 


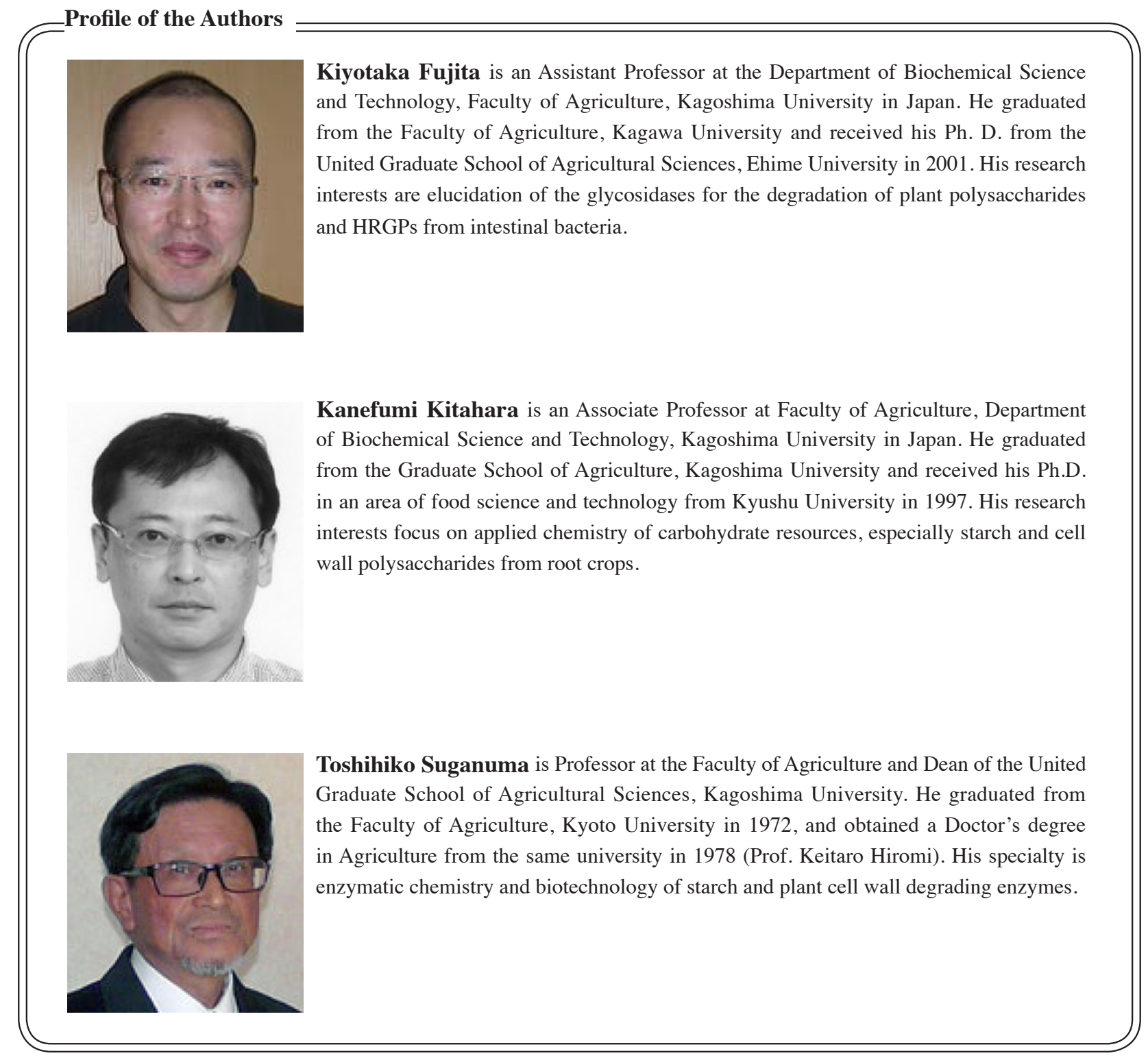

